\title{
Phospholipase $D$ is involved in oxidative stress-induced migration of vascular smooth muscle cells via tyrosine phosphorylation and protein kinase $C$
}

\author{
Joonmo Kim ${ }^{1}$, Gyesik Min ${ }^{2}$ \\ Young-Seuk $\mathrm{Bae}^{3}$ and Do Sik Min ${ }^{1,4}$ \\ 'Department of Physiology \\ College of Medicine, The Catholic University \\ Seoul 137-701, Korea \\ ${ }^{2}$ Department of Microbiological Engineering \\ Jinju National University \\ Chilam-dong 150, Jinju, Gyeongsangnam-do, Korea \\ ${ }^{3}$ Department of Biochemistry \\ College of Natural Sciences, Kyungpook National University \\ Daegu 702-701, Korea \\ ${ }^{4}$ Coressponding author: Tel, 82-2-590-1165; \\ Fax, 82-2-532-9575; E-mail, dsmin@cmc.cuk.ac.kr
}

Accepted 28 October 2003

Abbreviations: PKC, protein kinase C; PLD, phospholipase D; ROS, reactive oxygen species; VSMCs, vascular smooth muscle cells

\begin{abstract}
Oxidative stress has been implicated in mediation of vascular disorders. In the presence of vanadate, $\mathrm{H}_{2} \mathrm{O}_{2}$ induced tyrosine phosphorylation of PLD1, protein kinase $C-\alpha(P K C-\alpha)$, and other unidentified proteins in rat vascular smooth muscle cells (VSMCs). Interestingly, PLD1 was found to be constitutively associated with PKC- $\alpha$ in VSMCs. Stimulation of the cells by $\mathrm{H}_{2} \mathrm{O}_{2}$ and vanadate showed a concentration-dependent tyrosine phosphorylation of the proteins in PLD1 immunoprecipitates and activation of PLD. Pretreatment of the cells with the protein tyrosine kinase inhibitor, genistein resulted in a dose-dependent inhibition of $\mathrm{H}_{2} \mathrm{O}_{2}$-induced PLD activation. $\mathrm{PKC}$ inhibitor and down-regulation of PKC abolished $\mathrm{H}_{2} \mathrm{O}_{2}$-stimulated PLD activation. The cells stimulated by oxidative stress $\left(\mathrm{H}_{2} \mathrm{O}_{2}\right)$ caused increased cell migration. This effect was prevented by the pretreatment of cells with tyrosine kinase inhibitors, PKC inhibitors, and 1-butanol, but not 3-butanol. Taken together, these results suggest that PLD might be involved in oxidative stress-induced migration of VSMCs, possibly via tyrosine phosphorylation and PKC activation.
\end{abstract}

Keywords: migration; PKC; PLD; tyrosine phosphorylation

\section{Introduction}

Phospholipase D (PLD) catalyzes the hydrolysis of phosphatidylcholine (PC), the major membrane phospholipid, to form phosphatidic acid (PA) and choline. $P A$ is generally recognized as the signaling product of PLD and functions as an effector in multiple physiological processes. Although the precise physiological function of PLD in cells is poorly understood, receptor-stimulated PLD activity has been implicated in a broad range of physiological response such as rapid response (secretion and superoxide generation) and long-term responses (proliferation, differentiation, and immune response) (Exton, 1997; Exton, 1998; Exton, 1999; Liscovitch et al., 2000; Kim et al., 2003). To date, two PLD isoforms have been cloned and characterized (Hammond et al., 1995; Colley et al., 1997; Hammond et al., 1997). PLD1 has a low basal activity and is up-regulated by small $G$ proteins (ARF, Rho and Ral), protein kinase $C$ (PKC), and phosphatidylinositol 4, 5-bisphosphate $\left(\mathrm{PIP}_{2}\right)$ in vitro. In contrast, PLD2 has a high basal activity, requires $\mathrm{PIP}_{2}$, and is up-regulated by ARF and PKC. Although many studies focusing on the regulation of PLD have been reported, the cellular role of PLD remains still unclear.

Proliferation and migration of vascular smooth muscle cells (VSMCs) contribute to diverse vascular physiology and pathology such as wound healing, restenosis in grafted and injured vessels, and formation of the atherosclerotic lesion. Recent studies have shown that oxidative stress may potentiate smooth muscle cells migration (Sundaresan et al., 1995; Griendling et al., 1997). Enhanced migration of VSMCs plays an important role in the atherogenesis (Ross, 1999). Reactive oxygen species (ROS) including hydrogen peroxide and superoxide might function as intracellular messengers. In response to diverse stimuli including growth factors, ROS are produced in an array of paths from cells and are involved in regulation of cell growth, survival, and differentiation (Irani, 2000). $\mathrm{H}_{2} \mathrm{O}_{2}$ was reported to stimulate PLD activity in endothelial cells (Natarajan et al., 1993), Swiss3T3 fibroblast (Min et al., 1998), and PC12 cells (Ito et al., 1997). Oxidant stress due to $\mathrm{H}_{2} \mathrm{O}_{2}$ induced 
tyrosine phosphorylation of proteins that was strongly potentiated by combination with vanadate (Heffetz et al., 1990). The mechanism was proposed to be due, at least in part, to inhibition of protein-tyrosine phosphatase (Heffetz et al., 1990) or activation of proteintyrosine kinase activity (Koshio et al., 1988). Protein tyrosine phosphorylation is important in regulating signaling pathways through its effects on proteinprotein interactions. Oxidative stress has been implicated in mediation of vascular disorders. Given that, treatment of primary cultured cells such as VSMCs with oxidative stress may provide as a model system to explore a relationship between vascular disorder and PLD.

In the present study, the effect of hydrogen peroxide as a pharmacologic agent on the PLD activation and migration of VSMCs was investigated. We demonstrate that PLD is involved in oxidative stressinduced migration of VSMCs, possibly tyrosine phosphorylation and PKC activation.

\section{Materials and Methods}

\section{Materials}

Hydrogen peroxide, sodium orthovanadate, sodium deoxycholate, phenylmethylsulfonyl fluoride (PMSF), PMA and Nonidet P-40 were purchased from Sigma Chemical Co. (St. Louis, MO). Dulbecco's modified Eagle's medium (DMEM) and fetal bovine serum (FBS) were purchased from Invitrogen. Protein A Sepharose was from Amersham Bioscience (Uppsala, Sweden). Anti-phosphotyrosine antibody (P-Tyr) (4G10) were from Upstate Biotechnology (Lake Placid, NY), and genistein from Calbiochem (San Diego, CA). A polyclonal antibody that recognizes both PLD1 and PLD2 was generated as previously described (Min et al., 2001). Phosphatidylbutanol (PtdBut) standard was from Avanti Polar Lipid, Inc (Alablaster, AL). [9, 10${ }^{3} \mathrm{H}$ ]myristate was purchased from PerkinElmer Life Sciences (Boston, MA). Silica gel 60 A thin layer chromatography plates were from Whatman Inc. (Clifton NJ). Horseradish peroxidase-conjugated antimouse $\lg G$ and anti-rabbit $\lg G$ were from Kirkegaard \& Perry Lab (Gaithersburg, MD). The ECL western blotting detection kit was from Amersham Bioscience.

\section{Cell culture}

VSMCs were obtained by collagenase digestion of aortas from 7-week-old Sprague-Dawley rats (Chamley-Campbell et al., 1979). Cultured VSMCs showed the characteristic 'hills and valleys' growth pattern. VSMC purity was confirmed by immunofluorescence using smooth muscle-specific anti-actin antibody, VSMCs at six to nine passages were used for experiments.

\section{Phospholipase D assay}

PLD activity was assessed by measuring the formation of $\left[{ }^{3} \mathrm{H}\right]$ phosphatidylbutanol (PtdBut), the product of PLD-mediated transphosphatidylation, in the presence of 1-butanol. Cells were subcultured in 6-well plates at $2 \times 10^{5}$ cells/well and serum-starved in the presence of $\left.1 \mu \mathrm{Ci} / \mathrm{ml}^{3}{ }^{3} \mathrm{H}\right]$ myristic acid. After overnight starvation, the cells were washed three times with 5 $\mathrm{ml}$ of phosphate-buffered saline (PBS) and pre- equilibrated in serum-free DMEM for $1 \mathrm{~h}$. For the final 10 min of preincubation, $0.3 \%$ 1-butanol was included. At the end of the preincubation, cells were treated with agonists for the indicated times. The extraction and characterization of lipids by thin-layer chromatography were performed as previously described (Lee et al., 2000)

\section{Imm unoprecipitation}

Cells were washed twice with ice-cold phosphatebuffered saline and then lysed in the extraction buffer (20 mM Hepes, $\mathrm{pH} 7.2,1 \%$ Triton $\mathrm{X}-100,1 \%$ sodium deoxycholate, $0.2 \%$ SDS, $200 \mathrm{mM} \mathrm{NaCl}, 1 \mathrm{mM}$ $\mathrm{Na}_{3} \mathrm{VO}_{4}, 1 \mathrm{mM} \mathrm{NaF}, 10 \%$ glycerol, $10 \mu \mathrm{g} / \mathrm{ml}$ leupeptin, $10 \mu \mathrm{g} / \mathrm{ml}$ aprotinin, $1 \mathrm{mM}$ phenymethylsulfonyl fluoride). The resulting cell lysates were spun at $15,000 \mathrm{~g}$ in an Eppendorf microcentrifuge for $10 \mathrm{~min}$ at $4^{\circ} \mathrm{C}$ to pellet the unbroken cells. The supernatant was then reacted for $30 \mathrm{~min}$ with preimmune $\mathrm{IgG}$ and protein A Sepharose at $4{ }^{\circ} \mathrm{C}$ with rocking. Protein concentrations were determined using Bradford method with bovine serum albumin as a standard (Bradford, 1976). Equal protein aliquots of pretreated cell lysates $(1 \mathrm{mg})$ were incubated with the indicated antibodies and 40 $\mu \mathrm{l}$ of a $1: 1$ slurry of protein A Sepharose beads for $4 \mathrm{~h}$ at $4^{\circ} \mathrm{C}$. The immune complexes were collected by centrifugation and washed five times with a buffer (20 mM Tris, pH 7.5, 1 mM EDTA, 1 mM EGTA, 150 $\mathrm{mM} \mathrm{NaCl}, 2 \mathrm{mM} \mathrm{Na}_{3} \mathrm{PO}_{4}, 10 \%$ glycerol and $1 \%$ Nonidet $\mathrm{P}-40$ ) and resuspended in sample buffer. Immune complexes were boiled in SDS-sample buffer

\section{Western blotting}

Protein samples were analyzed by SDS-polyacrylamide gel electrophoresis on $8 \%$ gels and were transferred to a nitrocellulose membrane. The blots were then blocked with $5 \%$ non-fat milk and incubated with appropriate primary antibodies followed by incubation with horseradish peroxidase-conjugated secondary antibody. Immunoreactive bands were detected using enhanced chemiluminescence.

\section{Migration}

Cell migration was analyzed using Transwell (Nunc, Naperville, IL) containing polycarbonate membranes. 
Membranes were coated with $1 \%$ gelatin/well, and rinsed once with PBS. Cells were starved for $20 \mathrm{~h}$ with DMEM containing $0.2 \%$ FBS. Cells $\left(1 \times 10^{5}\right)$ were added to the chamber of a Transwell with M1999 containing $0.2 \%$ FBS and then allowed to migrate for $3 \mathrm{~h}$ at $37^{\circ} \mathrm{C}$. The cells were fixed with $2.5 \%$ glutaraldehyde for $10 \mathrm{~min}$. Non-migrating cells on the upper side of the membrane were removed with a cotton swab, and the invading cells that attached to the bottom membrane were stained with $0.1 \%$ crystal violet. The number of invading cells per membrane was counted on five random fields.

\section{Results}

\section{Hydrogen peroxide induces tyrosine phospho- rylation of PLD1 and other proteins in PLD1 immune complexs in VSMCs}

In order to examine the role of tyrosine phosphorylation in the activation of PLD of VSMCs, the cells cultured in serum-free media were treated with orthovanadate $(100 \mu \mathrm{M})$ for $20 \mathrm{~min}$ and then exposed to $\mathrm{H}_{2} \mathrm{O}_{2}(500 \mu \mathrm{M})$. The treated cell lysates were immunoprecipitated with antibody against PLD1. As shown in Figure 1, anti-PLD1 antibody precipitated tyrosinephosphorylated proteins of $170,125,85$, and $68 \mathrm{kDa}$ in the stimulated cells. To identify whether the 125 $\mathrm{kDa}$ tyrosine phosphorylated protein was PLD itself or an other associated protein, cell lysates were immunoprecipitated with anti-PLD1 antibody and sub-

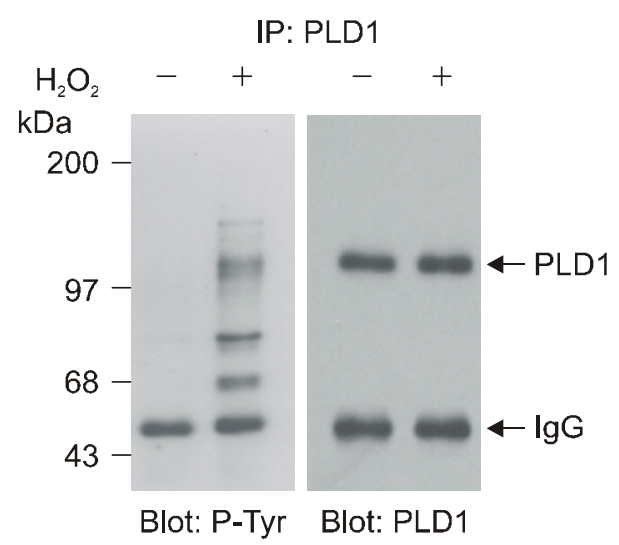

Figure 1. Hydrogen peroxide induces tyrosine phosphorylation of proteins in PLD1 immunoprecipitates in VSMCs. VSMCs were maintained in a serum-free medium for $24 \mathrm{~h}$, followed by pretreatment with orthovanadate $(100 \mu \mathrm{M})$ for $30 \mathrm{~min}$ and then stimulation without (lane 1) or with $500 \mu \mathrm{M} \mathrm{H}_{2} \mathrm{O}_{2}$ (lane 2) for $20 \mathrm{~min}$. Cells were then lysed, and immunoprecipitates (IP) were prepared using anti-PLD1 antibody. Immunoprecipitates were analyzed by SDS-polyacrylamide gel electrophoresis, followed by transfer of proteins to nitrocellulose paper and Western blotting (Blot) with anti-P-Tyr or anti-PLD1 antibody. Data are representative of three experiments. jected to Western blot analysis using anti-PLD1 antibody. The electrophoretic mobility of PLD correlated with that of the $125 \mathrm{kDa}$ phosphotyrosine protein (Figure 1). Equal amounts of PLD were immunoprecipitated from control and agonist-treated cells.

\section{Dose dependence of tyrosine phosphorylation and activation of PLD by $\mathrm{H}_{2} \mathrm{O}_{2}$}

To examine the dose-dependency of $\mathrm{H}_{2} \mathrm{O}_{2}$ on tyros-

A

IP: PLD1

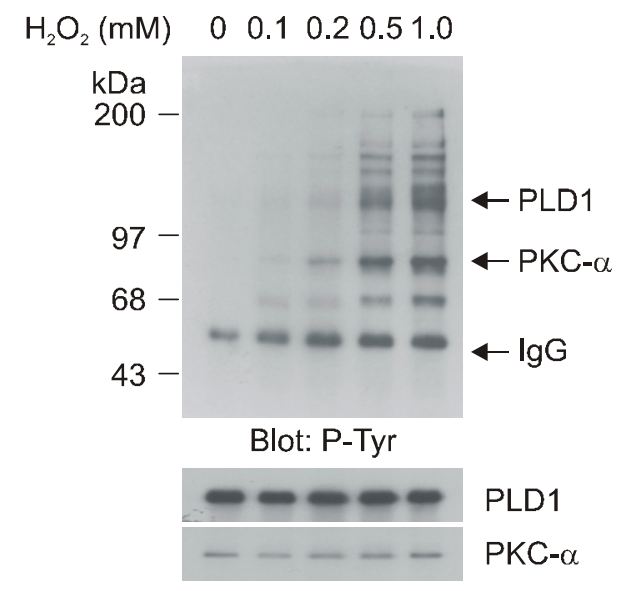

B

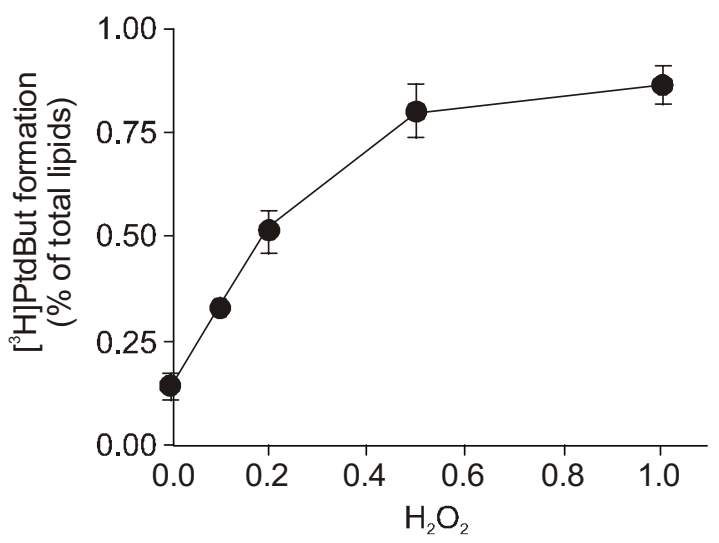

Figure 2. Dose dependence of tyrosine phosphorylation and PLD activation by $\mathrm{H}_{2} \mathrm{O}_{2}$ in VSMCs. (A) Quiescent cells were pretreated with orthovanadate $(100 \mu \mathrm{M})$ for $30 \mathrm{~min}$ and then stimulated with the indicated concentrations of $\mathrm{H}_{2} \mathrm{O}_{2}$. Equal amount of cell lysates were immunoprecipitated (IP) with anti-PLD1 antibody and Western blotted (Blot) with anti-P-Tyr antibody. The blots were stripped and reprobed with anti-PKC- $\alpha$ or PLD1 antibody. (B) VSMCs were radiolabeled with $1 \mu \mathrm{Ci} / \mathrm{ml}[3 \mathrm{H}] \mathrm{myristate}$, pretreated with vanadate, and preincubated with $0.3 \%$ butanol for $10 \mathrm{~min}$ prior to stimulation with the indicated concentrations of $\mathrm{H}_{2} \mathrm{O}_{2}$ for 20 min. The radioactivity incorporated into PtdBut was measured as described under "Materials and Methods". Data are representative of three independent experiments. 
ine phosphorylation of protein(s), quiescent VSMCs were pretreated with vanadate and then exposed to varying concentrations of $\mathrm{H}_{2} \mathrm{O}_{2}$ for $20 \mathrm{~min}$. The cell lysates were immunoprecipitated with anti-PLD1 antibody and subjected to immunoblotting with anti-P-Tyr antibody. No tyrosine-phosphorylated protein bands were detected in control cells (apart from IgG chains). At $0.01 \mathrm{mM} \mathrm{H}_{2} \mathrm{O}_{2}$, a light tyrosine phosphorylation was detected, but at 0.5 and $1 \mathrm{mM}$, dramatically elevated levels of tyrosine phosphorylation was observed on several proteins including $125 \mathrm{kDa}$ PLD1 and the PLD1 associated 170-, 85-, and $68 \mathrm{kDa}$ proteins (Figure 2A). Thus, tyrosine phosphorylation of those proteins in the PLD1 immune complex was induced dose-dependently on $\mathrm{H}_{2} \mathrm{O}_{2}$ concentration reaching a maximal level at 0.5 to $1 \mathrm{mM}$. As indicated on Figure 1 the $125 \mathrm{kDa}$ protein was PLD1, the blot stripped and reprobed with the anti-PLD1 antibody (Figure 2A) confirmed the presence of PLD in all lanes. However, the amounts were not altered by $\mathrm{H}_{2} \mathrm{O}_{2}$ stimulation.

Next, attempt was made to identify the $85 \mathrm{kDa}$ tyrosine-phosphorylated protein in the anti-PLD1 immunoprecipitates using antibodies to several known signaling molecules of similar molecular masses including PKC to confirm a report of $\mathrm{H}_{2} \mathrm{O}_{2}$ induced tyrosine phosphorylation of the PKC- $\alpha$. The PLD1 antibody immunoprecipitates of cell lysates blotted with PKC- $\alpha$ antibody positively showed the presence of $85 \mathrm{kDa}$ PKC- $\alpha$.

In VSMCs prelabelled with $\left[{ }^{3} \mathrm{H}\right]$ myristate and preincubated with vanadate and $0.3 \%$ 1-butanol, $\mathrm{H}_{2} \mathrm{O}_{2}$ stimulated $\left[{ }^{3} \mathrm{H}\right.$ ]phosphatidylbutanol (PtdBut) formation in a dose-dependent manner (Figure 2B). This result indicates some correlations between effects of $\mathrm{H}_{2} \mathrm{O}_{2}$ on tyrosine phosphorylation and activation of PLD.

\section{Effect of genistein, tyrosine kinase inhibitor on $\mathrm{H}_{2} \mathrm{O}_{2}$-induced tyrosine phosphorylation and PLD activation}

To explore further role of tyrosine kinase in the action of $\mathrm{H}_{2} \mathrm{O}_{2}$ on the phosphorylation and activation of PLD, cells were pretreated with various concentrations of genistein, an inhibitor of protein-tyrosine kinase, prior to stimulation with $500 \mu \mathrm{M} \mathrm{H} \mathrm{H}_{2} \mathrm{O}_{2}$ for $20 \mathrm{~min}$. Cell lysates were then subjected to immunoprecipitation using anti-PLD1 antibody, followed by immunoblotting with anti-P-Tyr antibody. Figure $3 \mathrm{~A}$ shows that pretreatment with genistein inhibited the $\mathrm{H}_{2} \mathrm{O}_{2}$-induced tyrosine phosphorylation of proteins in the PLD1 immunoprecipitates in a concentration-dependent fashion. We also examined the effects of the inhibitor on PLD activation by $\mathrm{H}_{2} \mathrm{O}_{2}$. Genistein attenuated the $\mathrm{H}_{2} \mathrm{O}_{2}$ mediated increase in PLD activation in a dosedependent manner (Figure 3B). However, like the tyrosine phosphorylation, the inhibition was only partial.
A

IP: PLD1

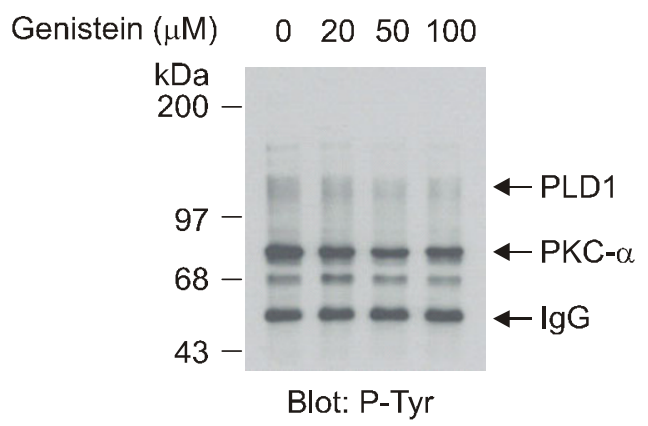

B

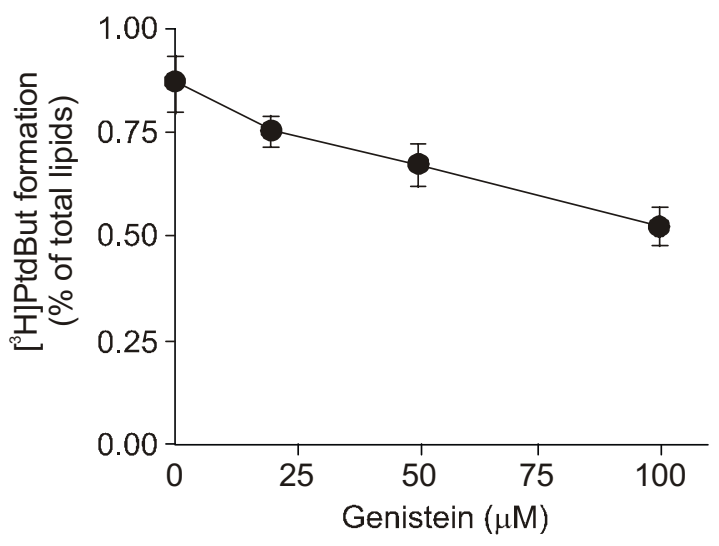

Figure 3. Effect of tyrosine kinase inhibitor on $\mathrm{H}_{2} \mathrm{O}_{2}$-induced tyrosine phosphorylation and PLD activation. (A) Quiescent cells were pretreated with the indicated concentrations of genistein for $40 \mathrm{~min}$ and with vanadate $(100 \mu \mathrm{M})$ for 30 min prior to stimulation with with 500 $\mu \mathrm{M} \mathrm{H}_{2} \mathrm{O}_{2}$ for 20 min. (B) $\left[{ }^{3} \mathrm{H}\right]$ myristate-labeled cells were pretreated with the indicated concentrations of genistein for $30 \mathrm{~min}$ and with vanadate $(100 \mu \mathrm{M})$ for 30 min and stimulated with $500 \mu \mathrm{M} \mathrm{H} \mathrm{H}_{2} \mathrm{O}_{2}$ for $20 \mathrm{~min}$. The radioactivity incorporated into PtdBut was measured as described under "Materials and Methods". Results are means \pm S.D of three independent experiments.

These results support the view that $\mathrm{H}_{2} \mathrm{O}_{2}$-mediated protein tyrosine phosphorylation is involved in PLD activation in VSMCs.

\section{Involvement of $P K C$ in the regulation of PLD}

A possible role of $\mathrm{PKC}$ in $\mathrm{H}_{2} \mathrm{O}_{2}$-stimulated PLD activation was examined by blocking PKC with the specific inhibitor and depleting the enzyme by prolonged exposure of cells to phorbol-12-myristate-13 acetate (PMA). PKC inhibitor, Gö6976 suppressed $\mathrm{H}_{2} \mathrm{O}_{2}$-induced PLD activation in a dose-dependent manner (Figure 4A). In addition, treatment of the cell with PMA for $24 \mathrm{~h}$ to down-regulate PKC abolished $\mathrm{H}_{2} \mathrm{O}_{2}$-stimulated PLD activity (Figure 4B). These results suggest that $\mathrm{PKC}$ is closely involved in PLD activation in the $\mathrm{H}_{2} \mathrm{O}_{2}$ induced stress response. 

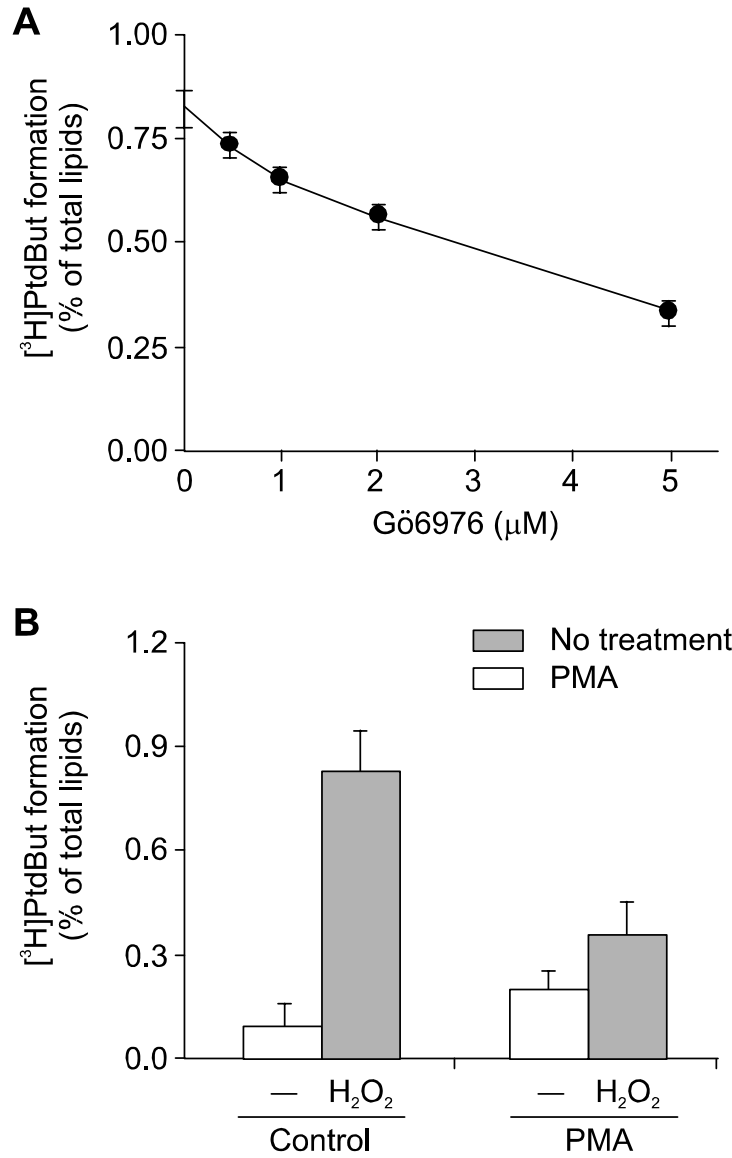

Figure 4. Effect of $\mathrm{PKC}$ inhibitor and $\mathrm{PKC}$ down-regulation on $\mathrm{H}_{2} \mathrm{O}_{2}$-induced PLD activation. (A) [ $\left.{ }^{3} \mathrm{H}\right]$ myristate-labeled cells were pretreated with the indicated concentrations of Gö6976 for 30 min and vanadate $(100 \mu \mathrm{M})$ prior to stimulation with $\mathrm{H}_{2} \mathrm{O}_{2}(500 \mu \mathrm{M})$ for 20 min. For down-regulation of PKC (B), $\left[{ }^{3} \mathrm{H}\right]$ myristate-labeled cells were pretreated without or with $500 \mathrm{nM}$ PMA for $24 \mathrm{~h}$ and then pretreated with vanadate prior to stimulation without or with $\mathrm{H}_{2} \mathrm{O}_{2}$ for $20 \mathrm{~min}$. The radioactivity incorporated into PtdBut was measured as described under "Materials and Methods". Results are means \pm S.D of three independent experiments.

\section{PLD is involved in the oxidative stress- induced migration of VSMCs via tyrosine kinase and PKC pathway}

To evaluate whether PLD activity is associated with VSMCs migration, cell migration was assessed in the absence or presence of inhibitors, prior to stimulation of $\mathrm{H}_{2} \mathrm{O}_{2}$. Oxidative stress increased the migration of VSMCs but a tyrosine kinase inhibitor, genistein and a PKC inhibitor, Gö6976, inhibited oxidative stressinduced migration of VSMCs (Figure 5). A role for PLD in the pathway associated with cell migration was further supported by the fact that 1-butanol blocks PA production by PLD by virtue of phosphatidylbutanol formation through the transphosphatidylation reaction. VSMCs were stimulated with $\mathrm{H}_{2} \mathrm{O}_{2}$

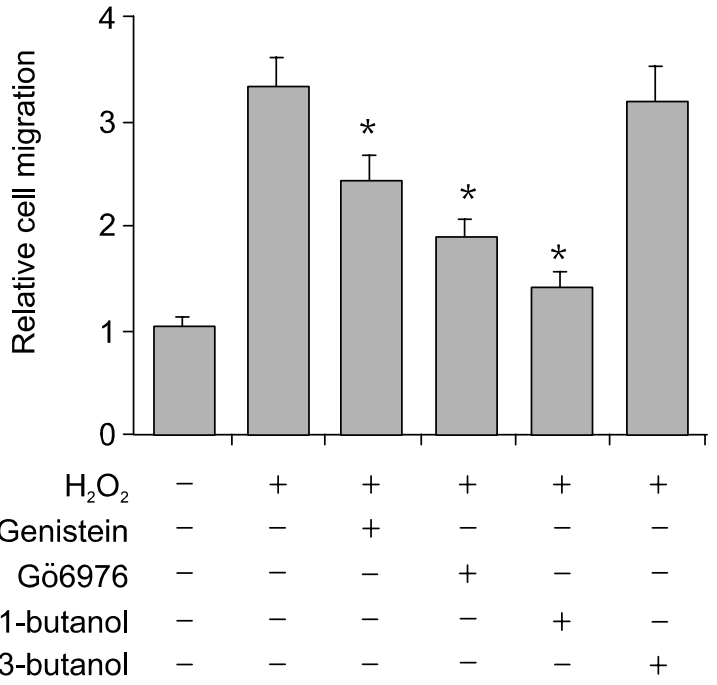

Figure 5. Effect of inhibitors on oxidative stress-induced migration of VSMCs. Cells were starved for $20 \mathrm{~h}$ with serum free media, and pretreated for the genistein $(100 \mu \mathrm{M})$, Gö6976 $(5 \mu \mathrm{M})$, 1-butanol $(0.5 \%)$, 3-butanol $(0.5 \%)$, and vanadate for $30 \mathrm{~min}$, and then stimulated with $500 \mu \mathrm{M} \mathrm{H}_{2} \mathrm{O}_{2}$ for $1 \mathrm{~h}$. Migration was analyzed by the procedure as described under "Materials and Methods". ${ }^{*} P<0.05$ compared to cells stimulated with $\mathrm{H}_{2} \mathrm{O}_{2}$. Results show means $\pm S . D$. of three independent experiments.

in the presence of 1\% 1-butanol or 3-butanol. As shown in Figure 5, 1-butanol but not 3-butanol, inhibited oxidative stress-induced migration. These results suggest that PLD activity is involved in oxidative stress-induced migration in VSMCs.

\section{Discussion}

In the present study, PLD was found to be involved in oxidative stress-stimulated migration of VSMCs. Oxidative stress is known to stimulate PLD activity in a various cells (Natarajan et al., 1993; Ito et al., 1997; Min et al., 2001; 2002), but its physiological function remains unclear. In this study, the effect of $\mathrm{H}_{2} \mathrm{O}_{2}$ was evaluated on the PLD activation and migration of VSMCs. Several studies indicated that tyrosine kinases participate in PLD activation. We observed that the serial treatment of the cell with vanadate and $\mathrm{H}_{2} \mathrm{O}_{2}$ induced strong tyrosine phosphorylation of PLD and its associated proteins. The protein tyrosine phosphorylation induced by $\mathrm{H}_{2} \mathrm{O}_{2}$ plus vanadate was blocked by pretreatment with the tyrosine kinase inhibitor, genistein. The associated PLD activation was also inhibited but partially by these agents. Tyrosine phosphorylation of PLD by $\mathrm{H}_{2} \mathrm{O}_{2}$ does not appear to be closely correlated with activation of the enzyme. Thus, activation mechanism involving another protein tyrosine phosphorylation needs to be considered. The fact that PKC- $\alpha$ is tyrosine phosphorylated in re- 
sponse to $\mathrm{H}_{2} \mathrm{O}_{2}$ and inhibition and down-regulation of PKC- $\alpha$ also effects $\mathrm{H}_{2} \mathrm{O}_{2}$ induced PLD activation does clearly indicated that PKC- $\alpha$ could be a dominant player in oxidative stress induced protein tyrosine phosphorylation path. Although $\mathrm{H}_{2} \mathrm{O}_{2}$ causes tyrosine phosphorylation of PLD, this cannot fully explain the activation of the enzyme. The possibility that tyrosine phosphorylation of PKC- $\alpha$ or another regulatory protein is responsible for the activation of PLD needs further exploration.

It has been shown that $\mathrm{H}_{2} \mathrm{O}_{2}$ directly inhibits protein-tyrosine phosphatase activity (Hecht et al., 1992) and that all protein-tyrosine phosphatase contain an essential sulfhydryl group that is crucial for activity and susceptible to oxidation (Stone et al., 1994). Thus, it seems probable that a protein-tyrosine phosphatase is a target of $\mathrm{H}_{2} \mathrm{O}_{2}$ in the present study. Inactivation of protein-tyrosine phosphatase would be expected to result in increased tyrosine phosphorylation since their specific activities in vitro are 10-1,000 times those of protein-tyrosine kinase (Fisher et al., 1991). In the presence of $\mathrm{H}_{2} \mathrm{O}_{2}$, orthovanadate is oxidized to pervanadate, which could facilitate its entry into cells. It is known that vanadate seems to play a dual role in potentiating effects on protein tyrosine phosphorylation.

Recently, it has been suggested that the increase in oxidative stress may play a role in the increase in the rate of migration of smooth muscle cells (Ross, 1999). Recent studies have shown that angiotensin II induces migration of human coronary smooth muscle cells through increase in oxidative stress (Yasunari et al., 2002). Enhanced migration of VSMCs plays an important role in the atherogenesis (Ross, 1999). Recent study indicated that PLD activation is involved in the epithelial cell migration (Santy and Casanova, 2001) and PKC was implicated in the cell migration (Dempsey et al., 2000). In this study, oxidative stress on VSMCs caused stimulation of PLD activity, possibly via tyrosine kinase and PKC activation. Inhibitors of tyrosine kinase and PKC suppressed oxidative stress-induced cell migration. In addition, blocking PA production by PLD inhibited oxidative stress-induced migration of VSMCs. These results suggest that PLD activity is involved in oxidative stress-induced migration in VSMCs. Recently, we have reported that activity and expression of PLD1 from spontaneously hypertensive rats increased significantly in the liver and brain compared to those of their normotensive control rats, suggesting involvement of PLD in the pathogenesis of hypertension (Min et al., 2001). Future therapeutic strategies for vascular protection in hypertensive patients may include direct targeting of the signaling pathways to prevent oxidative stress in vascular tissue.

\section{Acknowledgement}

This work was supported by grant No. R01-2002000-00262-0 (2002) from the Basic Research Program of the Korea Science \& Engineering Foundation.

\section{References}

Ben-AV P, Liscovitch M. Phospholipase D activation by the mitogens platelet-derived growth factor and 12-0-tetradecanoylphorbol 13-acetate in NIH-3T3 cells. FEBS Lett 1989; 259:64-7

Bradford MM. A rapid and sensitive method for the quantitation of microgram quantities of protein utilizing the principle of protein-dye binding. Anal Biochem 1976;72:248-54

Chamley-Campbell J, Campbell GR, Ross R. The smooth muscle cell in culture. Physiol Rev 1979;59:1-61

Colley WC, Sung R, Jenco RL, Hammond SM, Altshuller $Y$, Bar-Sagi D, Morris AJ, Frohman MA. Phospholipase D2, a distinct phospholipase $D$ isoform with novel regulatory properties that provokes cytoskeletal reorganization. Curr Biol 1997;7:191-201

Dempsey EC, Newton AC, Mochly-Rosen D, Fields AP, Reyland $\mathrm{ME}$, Insel PA, Messing, RO. Protein kinase $C$ isozymes and the regulation of diverse cell responses. Am J Physiol Lung Cell Mol Physiol 2000;279:L429-38

Exton JH. Phospholipase D: enzymology, mechanisms of regulation, and function. Physiol Rev 1997;77:303-20

Exton JH. Phospholipase D. Biochim Biophys Acta 1998; 1436:105-15

Exton JH. Regulation of phospholipase D. Biochim Biophys Acta 1999;1439:121-33

Fisher EH, Charbonneau H, Tonks NK. Protein tyrosine phosphatases: a diverse family of intracellular and transmembrane enzymes. Science 1991;253:401-6

Fisher GJ, Henderson PA, Voorhees JJ, Baldassare JJ. Epidermal growth factor-induced hydrolysis of phosphatidylcholine by phospholipase $D$ and phospholipase $C$ in human dermal fibroblasts. J Cell Physiol 1991;146:309-17

Griendling KK, Ushio-Fukai M, Lassegue B, Alexander RW. Angiotensin II signaling in vascular smooth muscle: new concepts. Hypertension 1997;29:366-73

Hammond SM, Altshuller YM, Sung TC, Rudge SA, Ross $\mathrm{K}$, Engebrecht J, Morris AJ, Frohman MA. Human ADPribosylation factor-activated phosphatidylcholine-specific phospholipase $D$ defines a new and highly conserved gene family. J Biol Chem 1995;270:29640-3

Hammond SM, Jenco JM, Nakashima S, Cadwallader K, Gu QM, Cook S, Nozawa Y, Prestwich GD, Frohman MA, Morris AJ. Human ADP-ribosylation factor-activated phosphatidylcholine-specific phospholipase $D$ defines a new and highly conserved gene family. J Biol Chem 1997;272:3860-8

Hecht D, Zick Y. Selective inhibition of protein tyrosine phosphatase activities by $\mathrm{H}_{2} \mathrm{O}_{2}$ and vanadate in vitro. Biochem Biophys Res Commun 1992;88:773-9 
Heffetz D, Bushkin I, Dror R, Zick Y. The insulinomimetic agents $\mathrm{H}_{2} \mathrm{O}_{2}$ and vanadate stimulate protein tyrosine phosphorylation in intact cells. J Biol Chem 1990;265:2896-902

Houle MG, Bourgoin S. Regulation of phospholipase $D$ by phosphorylation-dependent mechanisms. Biochim Biophys Acta 1999;1439:135-50

Irani K. Oxidant signaling in vascular cell growth, death, and survival: A review of the roles of reactive oxygen species in smooth muscle and endothelial cell mitogenic and apoptotic signaling. Circ Res 2000;87:179-83

Ito $\mathrm{Y}$, Nakashima $\mathrm{S}$, Nozawa $\mathrm{Y}$. Hydrogen peroxide-induced phospholipase $\mathrm{D}$ activation in rat pheochromocytoma PC12 cells: possible involvement of $\mathrm{Ca}^{2+}$-dependent protein tyrosine kinase. J Neurochem 1997;69:729-36

Kim KO, Lee KH, Kim YH, Park SK, Han JS. Anti-apoptotic role of phospholipase $\mathrm{D}$ isozymes in the glutamate-induced cell death. Exp Mol Med 2003;35:38-45

Koshio O, Akanuma Y, Kasuga M. Hydrogen peroxide stimulates tyrosine phosphorylation of the insulin receptor and its tyrosine kinase activity in intact cells. Biochem J 1998; 250:95-101

Lee MY, Jo YH, Chun MH, Chung JW, Kim MS, Min DS. Immunohistochemical localization of phospholipase D1 in rat central nervous system. Brain Res 2000;864:52-9

Liscovitch M, Czarny M, Fiucci G, Tang X. Phospholipase $D$ : molecular and cell biology of a novel gene family. Biochem J 2000;345:401-15

Min DS, Kim EG, Exton JH. Involvement of tyrosine phosphorylation and protein kinase $\mathrm{C}$ in the activation of phospholipase $\mathrm{D}$ by $\mathrm{H}_{2} \mathrm{O}_{2}$ in Swiss $3 \mathrm{~T} 3$ fibroblasts. $\mathrm{J}$ Biol Chem 1998;273:29986-94

Min DS, Ahn BH, Jo YH. Differential tyrosine phosphorylation of phospholipase $D$ isozymes by hydrogen peroxide and the epidermal growth factor in A431 epidermoid carcinoma cells Mol Cells 2001;11:369-78

Min, DS, Ahn BH, Rhie DJ, Yoon SH, Hahn SJ, Kim MS, Jo $\mathrm{YH}$. Expression and regulation of phospholipase $\mathrm{D}$ during neuronal differentiation of PC12 cells. Neuropharmacology 2001;41:384-39

Min DS, Lee KH, Chang JS, Ahn BH, Rhie DH, Yoon SH, Hahn SJ, Kim MS, Jo YH. Altered expression of phospholipase D1 in spontaneously hypertensive rats. Mol Cells 2001;11:386-91

Min DS, Shin EY, Kim EG. The p38 mitogen-activated protein kinase is involved in stress-induced phospholipase $D$ activation in vascular smooth muscle cells. Exp Mol Med 2002;34:38-46

Natarajan V, Taher MM, Roehm B, Parinandi NL, Schmid HHO, Kiss X, Garcia JGN. Activation of endothelial cell phospholipase $D$ by hydrogen peroxide and fatty acid hydroperoxide. J Biol Chem 1993;268:930-7

Ross R. Atherosclerosis: an inflammatory disease. N Eng J Med 1999;340:115-26

Santy LC, Casanova JE. Activation of ARF6 by ARNO stimulates epithelial cell migration through downstream activation of both Rac1 and phospholipase D. J Cell Biol 2001; 154:599-610

Stone RL, Dixon JE. Protein-tyrosine phosphatases. J Biol Chem 1994;269:31323-6

Sundaresan M, Yu ZX, Ferrans VJ, Irani K, Finkel T. Requirement for generation of for platelet-derived growth factor signal transduction. Science 1995;270:296-9

Yasunari K, Maeda K, Nakamura M, Yoshikawa J. Pressure promotes angiotensin II-mediated migration of human coronary smooth muscle cells through increase in oxidative stress. Hypertension 2002;39:433-7 